\title{
The Culture in vitro of the Rumen Bacterium Quin's Oval
}

\author{
By C. G. ORPIN \\ Department of Biochemistry, Agricultural Research Council, \\ Institute of Animal Physiology, Babraham, Cambridge, CB2 $4 A T$
}

(Received 3 July 1972)

\section{SUMMARY}

The rumen bacterium Quin's Oval has been maintained anaerobically in vitro for more than I year in liquid culture at $39{ }^{\circ} \mathrm{C}$, in the presence of other bacteria, rumen fluid, lactate, $n$-valerate, isovalerate, DL- $\alpha$-methylbutyrate, L-cysteine, mannitol and a $\mathrm{CO}_{2}$ gas phase. The maximum population density attained was $8 \cdot \mathrm{I} \times$ $10^{6} / \mathrm{ml}$. No growth was obtained in sterile media or in solid media. Growth and glycogen storage occurred when the organisms were incubated with mannitol, glucose, fructose, mannose and sucrose; amino acids, proteins and polysaccharides were not so utilized. The organisms did not survive freezing, but were viable after 2 weeks at $4{ }^{\circ} \mathrm{C}$. The morphology as seen in the light microscope and the staining of the organisms is described.

\section{INTRODUCTION}

Quin's Oval (Q.O.) was first described briefly by Woodcock \& Lapage (I9I3) and later by Quin (1943). The latter author observed large numbers of oval organisms in the rumen of a sheep fed on lucerne. He named the organism Schizosaccharomyces ovis in the belief that it was a yeast, but subsequent workers concluded that this was not so (Ingram \& McGaughey, I948; van der Westhuizen, Oxford \& Quin, I950; Oxford, 1955) on the grounds that the organism would not grow in conventional yeast media, was motile and Gram-negative. Positive evidence for its status as a bacterium was supplied by Wicken \& Howard (I967) who identified 2,4-diaminopimelate and muramate in cell wall preparations of Q.O. Q.O. has not been allocated a taxonomic position or scientific name; workers have been content to identify the organism by its colloquial name. Q.O. is a normal member of the rumen microbial population, occurring in every sheep so far examined at the author's laboratory; the population has varied from $1 \cdot 9 \times 10^{5}$ to $3 \cdot 0 \times 10^{8} / \mathrm{ml}$. Q.O. has also been observed by the author in the rumen of cattle and of a llama and may therefore have a wide distribution amongst ruminants.

The fermentation of carbohydrates by Q.O. and the nature of the storage polysaccharide of Q.O. have been examined (Brough \& Howard, 1970; Brough, Reid \& Howard, 1970; Every \& Howard, 1970), but the organisms used were not grown in vitro. As far as the author is aware, the present paper is the first recorded instance of the culture in vitro of Q.O., although R. J. Moir (personal communication) has maintained Q.O. in vitro for short periods. Other workers have not been successful (for instance, Purdom, 1963). A preliminary communication (Orpin, 1972b) has already been published. 


\section{METHODS}

Culture media. The standard medium (medium A) consisted of a solution in $10 \%(\mathrm{v} / \mathrm{v})$ autoclaved rumen fluid (Orpin, I972 $a$ ) containing (g/l): $\mathrm{KH}_{2} \mathrm{PO}_{4}, 4.9 ; \mathrm{K}_{2} \mathrm{HPO}_{4}, 2.8 ; \mathrm{NaCl}$, $\mathrm{I} \cdot 27 ; \mathrm{CaCl}_{2}$ (dried), $0.035 ; \mathrm{MgSO}_{4} \cdot 7 \mathrm{H}_{2} \mathrm{O}, 0.07 ; \mathrm{NaHCO}_{3}, 6.5$; sodium lactate, $0 . \mathrm{I}$; mannitol $0.2 ;$ L-cysteine hydrochloride (neutralized immediately before use), $0.2 ; n$-valerate, 0.088 ; isovalerate, 0.088 ; DL- $\alpha$-methylbutyrate, 0.088 . This medium was also modified by the addition of $(\mathrm{g} / \mathrm{l})$ : sodium acetate, $\mathrm{I} \cdot 74$; propionate, 0.59 ; and butyrate, 0.37 ; and designated medium $\mathrm{B}$. The medium was equilibrated with $\mathrm{CO}_{2}$ and dispensed, with $\mathrm{CO}_{2}$ flowing through all containers, into 6 inch $\times \frac{5}{8}$ inch tubes, in $10 \mathrm{ml}$ vol. Each tube was then bubbled vigorously with $\mathrm{CO}_{2}$ for at least $\mathrm{I}$ min and the tube sealed with a rubber bung as the gassing pipette was withdrawn.

Sterile media were prepared by autoclaving the inorganic salts (excluding the sodium bicarbonate) at I $15^{\circ} \mathrm{C}$ for $20 \mathrm{~min}$. The L-cysteine, sodium bicarbonate, mannitol, sodium lactate and volatile faty acids solutions were sterilized separately using a Swinney-type hypodermic adapter with a glass-fibre filter, type A (Gelman Instrument Co., Ann Arbor, Michigan, U.S.A.) and, with the autoclaved rumen fluid, added aseptically to the sterile salts solution.

Solid media were prepared by the addition to the medium of $\mathrm{I} \%$ agar (Davis) and $0.001 \%$ resazurin, and the medium decolorized by bubbling with $\mathrm{CO}_{2}$ passed over heated copper. Inoculation was performed with $\mathrm{O}_{2}$-free $\mathrm{CO}_{2}$ flowing over the medium kept at $45{ }^{\circ} \mathrm{C}$; the inoculated medium was mixed and allowed to cool. Unless otherwise stated, all inoculated media were incubated at $39{ }^{\circ} \mathrm{C}$.

Rumen fluid fractions. Rumen fluid from a Clun Forest wether, fed daily on $800 \mathrm{~g}$ of hay chaff and $200 \mathrm{~g}$ of rolled oats, was strained through one layer of muslin to remove coarse plant material. The strained rumen fluid was centrifuged at $1000 \mathrm{~g}$ for $5 \mathrm{~min}$ to sediment the protozoa, large bacteria and larger plant material; the supernatant was autoclaved under $\mathrm{CO}_{2}$ to produce 'autoclaved rumen fluid' (ARF). The same supernatant was centrifuged at $2500 \mathrm{~g}$ for $30 \mathrm{~min}$ to yield particulate fraction $\mathrm{A}$. The supernatant from this was then centrifuged successively at $7500 \mathrm{~g}$ for $30 \mathrm{~min}$ and $\mathrm{I} 2500 \mathrm{~g}$ for $30 \mathrm{~min}$ to yield particulate fractions $B$ and $C$ respectively. Each fraction was washed twice by centrifugation in the salts solution used in the standard culture medium and resuspended, to the original volume of rumen fluid, in the salts solution and autoclaved (I $5{ }^{\circ} \mathrm{C}$, I $5 \mathrm{~min}$ ). The rumen fluid supernatant from the last centrifugation was autoclaved to produce 'autoclaved supernatant' (AS). Strained rumen fluid was also centrifuged at $38000 \mathrm{~g}$ for $\mathrm{I} h$, sterilized by filtration using a sintered glass filter (pore size $0.5 \mu \mathrm{m}$ ) and designated 'fresh, centrifuged, rumen fluid' (FCRF).

Counting and measurement. The organisms were counted using a conventional haemocytometer chamber with Thoma ruling, depth $0.1 \mathrm{~mm}$. The Ovals were incubated with $0.2 \mathrm{~g} / \mathrm{l}$ of mannitol for $15 \mathrm{~min}$ before counting in order that the viable organisms could be differentiated from non-viable organisms by their refractivity. When less than 20 Q.O./ml were present, four samples were counted and an average calculated. Samples that could not be counted immediately were fixed with $0.1 \mathrm{ml}$ of formalin/ $\mathrm{ml}$ of sample. Dimensions were determined using a calibrated micrometer eyepiece.

Isolation. The Ovals were isolated from crude rumen fluid using the following methods. Fresh rumen fluid from a Clun Forest wether, previously defaunated with sodium dioctylsulphosuccinate (Abou Akkada et al. 1968; Orpin, I97I) and containing $8.4 \times 10^{8} / \mathrm{ml}$ of Q.O., was first filtered through one layer of muslin to remove coarse particulate material. 
The filtrate $(25 \mathrm{ml})$ was diluted $\mathrm{I}: 2$ with the salts solution used in the culture medium containing $0.2 \mathrm{~g} / \mathrm{l}$ of L-cysteine in a $100 \mathrm{ml}$ measuring cylinder, bubbled thoroughly with $\mathrm{CO}_{2}$, and stood in an incubator at $39^{\circ} \mathrm{C}$ for $\mathrm{I} 5 \mathrm{~min}$ to sediment. The supernatant was decanted and centrifuged under $\mathrm{CO}_{2}$ for $5 \mathrm{~min}$ at $500 \mathrm{~g}$ to sediment large particulate material not removed by the previous sedimentation. The supernatant from this centrifugation was centrifuged under $\mathrm{CO}_{2}$ at $1000 \mathrm{~g}$ for $10 \mathrm{~min}$ and the pellet containing the Q.O. was suspended in $50 \mathrm{ml}$ of salts solution containing $0.2 \mathrm{~g} / 1$ of L-cysteine. The organisms were washed four more times by centrifugation under the same conditions in order to remove most of the contaminating bacteria. The Ovals were then inoculated into medium B and incubated under $\mathrm{CO}_{2}$, and the supernatant fluid replaced with fresh medium B every 2 days. After 2 weeks, 80 Q.O. organisms were removed by micromanipulation and incubated in $0.5 \mathrm{ml}$ of medium B under the same conditions. The supernatant was replaced with fresh medium every day for 2 weeks. The population density was then $4 \times 10^{4} / \mathrm{ml}$ and high enough to enable the volume to be increased to $5^{\circ} \mathrm{ml}$. After a further 2 weeks of the same treatment, when the population density had reached $7 \cdot 2 \times 10^{5} / \mathrm{ml}$, the volume was increased to Io $\mathrm{ml}$, after which the cultures were maintained by replacing the supernatant fluid once each week and 3 days later each week dividing the cultures into two and making each culture up to the original volume with fresh medium. This treatment is hereafter referred to as 'division'. Mannitol $(0.2 \mathrm{~g} / 1)$ was added each day with the exception of the day after the replacement of the supernatant or the division of the culture. Cultures of $50 \mathrm{ml}$ were established by bulking two well-grown $\mathrm{Io} \mathrm{ml}$ cultures in an 8 inch $\times \mathrm{I}$ inch tube and making the volume up to $50 \mathrm{ml}$ with fresh medium.

In attempts to obtain clone cultures of Q.O. free of other bacteria individual organisms were selected by micromanipulation and a number incubated together in sterile medium $B$ or in the medium of Caldwell \& Bryant (1966).

After several weeks in culture it was ascertained that culture medium A provided growth as good as that provided by medium $\mathrm{B}$ used during the isolation procedures; the standard culture medium A was therefore adopted for routine use.

Maintenance of cultures. Cultures were fed daily with $0.2 \mathrm{~g} / \mathrm{l}$ of mannitol, with the exception of the day following the division of the culture or the day after the replacement of the culture supernatant. It was necessary to examine each culture at least once per week, and, if growth of Q.O. was not good, or the growth of contaminating bacteria excessive, the supernatant was replaced with fresh medium for the following 2 days. If the growth of the Q.O. was not restored to its normal rate, the culture was discarded. Large numbers of contaminating bacteria were invariably correlated with a drop in the growth rate, or death, of the Q.O.

Preparation of inocula used in growth experiments. Inocula used in growth experiments in which the experimental medium varied from the standard culture medium were prepared as follows: the Ovals were sedimented from well-grown $\mathrm{IO} \mathrm{ml}$ cultures by centrifugation at Iooo $\mathrm{g}$ for $5 \mathrm{~min}$ at $2 \mathrm{I}{ }^{\circ} \mathrm{C}$ under $\mathrm{CO}_{2}$. The loose pellet was suspended in medium $\mathrm{A}$ from which were omitted the ARF and the component(s) whose effect on growth was to be examined. The Ovals were then washed by five centrifugations under the same conditions and finally resuspended in $10 \mathrm{ml}$ of the same medium. This suspension $(\mathrm{I} \cdot 0 \mathrm{ml})$ was then used to inoculate tubes containing $9.0 \mathrm{ml}$ of experimental medium. For experiments using different gas phases the centrifuging medium was gassed with, and all transfers during the handling performed under, the appropriate gas phase. Sodium bicarbonate was omitted from the medium when $\mathrm{N}_{2}, 95 \% \mathrm{~N}_{2}+5 \% \mathrm{CO}_{2}$ or air were the experimental gas phases.

Preparation of suspensions of Q.O. essentially free of other bacteria. The supernatants of several growing cultures were sucked off, leaving the Q.O. in the sediments in the bottom 
of the tubes. The combined sediments were made up to $100 \mathrm{ml}$ in a measuring cylinder with the salts solution used in medium A, containing $0.2 \mathrm{~g} / 1$ of L-cysteine, and equilibrated with $\mathrm{CO}_{2}$. The suspension was allowed to stand for $30 \mathrm{~min}$ at $39{ }^{\circ} \mathrm{C}$ to allow the larger particulate material to sediment. The supernatant was siphoned off, centrifuged at $200 \mathrm{~g}$ for $5 \mathrm{~min}$ at $5{ }^{\circ} \mathrm{C}$ to sediment large particulate material and then at $800 \mathrm{~g}$ for $20 \mathrm{~min}$ at $5{ }^{\circ} \mathrm{C}$ to sediment the Q.O. The Q.O. formed a cream-coloured layer on top of a brownish layer of particulate material and were washed free of the particulate material using the salts solution saturated with $\mathrm{CO}_{2}$. Repeated centrifugation at $800 \mathrm{~g}$ for $15 \mathrm{~min}$ at $5{ }^{\circ} \mathrm{C}$ and resuspension of the pellet washed the Q.O. essentially free of contaminating small bacteria. The number of centrifugings required varied with each batch of organisms, as the contaminating bacteria and particle size distribution in the rumen fluid used in the culture medium were variable. Average preparations contained I other bacterium to I00 Q.O. organisms, as determined by phase-contrast microscopy.

Estimation of glycogen. A cell suspension $(\mathrm{I} \cdot \mathrm{O} \mathrm{ml})$ was sedimented by centrifuging at I $000 \mathrm{~g}$ for $\mathrm{I} 5 \mathrm{~min}$, and the pellet was resuspended in I $\mathrm{ml}$ of $20 \%(\mathrm{w} / \mathrm{v}) \mathrm{KOH}$ and heated on a boiling-water bath for $30 \mathrm{~min}$. The mixture was centrifuged at $2600 \mathrm{~g}$ for $30 \mathrm{~min}$, and the glycogen precipitated, as a fine suspension, from the supernatant with $3.5 \mathrm{vol}$. of ethanol. This was aggregated by bringing to boiling point on a boiling-water bath. The tube was allowed to cool and centrifuged at $2600 \mathrm{~g}$ for I $5 \mathrm{~min}$; the sedimented glycogen was then washed twice by centrifugation in ethanol, and dried in a stream of air. The glycogen was hydrolysed with $\mathrm{I} \cdot \mathrm{O} \mathrm{ml}$ of $2 \mathrm{M}-\mathrm{HCl}$ in a boiling-water bath for $20 \mathrm{~min}$, and the liberated glucose estimated by the method of Park \& Johnson (1949).

\section{RESULTS}

Morphology and staining. The size of Q.O. organisms grown in vitro averaged $7 \cdot \mathrm{I} \times 3 \cdot \mathrm{I} \mu \mathrm{m}$ with a range of 5.8 to $8.0 \times 2.5$ to $3.6 \mu \mathrm{m}$ and did not show such a large variation as in vivo, where Ovals vary from $4 \times 2.5$ to $9 \times 3 \mu \mathrm{m}$ (Hungate, I966). However, when cultures remained undivided for more than 3 weeks, or when bacterial growth became excessive, elongated organisms of up to $40 \times 4 \mu \mathrm{m}$ were observed. In these cultures normal cell division was inhibited, as chains of up to six apparently normal or elongated cells were observed. Q.O. was iodophilic, normally staining dark brown. The degree of staining was variable, depending on the state of nutrition of the organisms. Ovals not fed for 2 days were not iodophilic. The distribution of staining was uniform in the elongated cells.

Q.O. was observed to be motile, although no flagella were seen after staining using the method of McCarthy \& Stevenson (I972). Movement was usually erratic, with the Q.O. not often moving more than a few organism lengths in a straight line. Continuous forward movement was accomplished by the cell describing an approximately helical course. Organisms grown in vitro were only motile soon after the addition of carbohydrate fermentable by the organism. Observations showed that in the rumen Q.O. organisms were motile at any time, though maximum motility occurred during the period in which the host animal was eating and shortly afterwards.

Q.O. was Gram-negative; no nuclear material was observed after staining with Feulgen stain, either in normal organisms or organisms starved for $48 \mathrm{~h}$. No lipid reserves were visualized using Sudan G. The contents of Q.O. stained with Best's carmine and were brown in Lugol's iodine, indicating the presence of glycogen. No capsule was demonstrable.

Q.O. divided by binary fission to yield daughter organisms of equal size. No spores were observed at any time during culture, or in organisms in vivo. 
Phase-contrast microscopy of growing Q.O. organisms showed them to be refractile with no visible cellular constituents. The refractivity decreased with time when no mannitol was added to the cells, and after $4^{8 \mathrm{~h}}$ the organisms were no longer refractile. Iodine staining showed a decrease in glycogen content correlated with the decrease in refractivity, and showed that the glycogen near the periphery of the organisms was utilized before that in the centre.

\section{Cultural conditions}

The effects of varying in turn certain medium constitutents and cultural conditions are shown below. The experiments were conducted using medium A ( $9 \mathrm{ml}$ ) modified as required. This was inoculated with a suspension of organisms prepared as under Methods.

Reducing agents. No growth occurred when the reducing agent was omitted, and the population density fell from $26 \times 10^{4} / \mathrm{ml}$ to zero within 4 days. In the presence of $0 \cdot 2 \mathrm{~g} / \mathrm{l}$ of Lcysteine, the population density rose to $49 \times \mathrm{IO}^{4} / \mathrm{ml}$; in the presence of $0.2 \mathrm{~g} / \mathrm{l}$ of sodium thioglycollate, sodium sulphide, 2-mercaptoethanol, ascorbic acid or dithiothreitol it changed to $37 \times 10^{4}$, zero, $32 \times 10^{4}, 1 \times 10^{4} / \mathrm{ml}$ and zero respectively.

Gas phase. Carbon dioxide was found to be the best gas phase of those tested. Population densities recorded after 4 days of incubation under the respective gases from an initial inoculum of $36 \times \mathrm{IO}^{4} / \mathrm{ml}$, were (organisms $/ \mathrm{ml}$ ): $\mathrm{CO}_{2}, 6 \mathrm{I} \times \mathrm{IO}^{4} ; 5 \% \mathrm{CO}_{2}+95 \% \mathrm{~N}_{2}, 38 \times \mathrm{IO}^{4}$; $\mathrm{N}_{2}, 8 \times \mathrm{IO}^{4}$; and air, $\mathrm{o}$.

Temperature. The best temperature for growth was $39^{\circ} \mathrm{C}$. At $44{ }^{\circ} \mathrm{C}$ Q.O. grew at the same initial rate, but after 2 weeks as many as $50 \%$ of the organisms elongated to up to 5 times the normal cell length, even if the medium was replaced every day. At 25 and $50{ }^{\circ} \mathrm{C}$, no growth occurred and the Q.O. died within 5 days. After incubation at $4{ }^{\circ} \mathrm{C}$ for 2 weeks, cultures were removed, the supernatant fluid was replaced with fresh medium $\mathrm{A}$, and the cultures incubated at $39^{\circ} \mathrm{C}$. The cultures still contained viable cells, as demonstrated by their ability to store glycogen in the presence of added mannitol, but their initial growth rate was decreased to $30 \%$ of normal. The normal growth rate was attained after 8 days. Cultures were also frozen at $-20{ }^{\circ} \mathrm{C}$, with and without the addition of $20 \%(\mathrm{v} / \mathrm{v})$ of glycerol. After 2 days, the cultures were thawed, the supernatant fluid replaced with fresh medium $A$, and incubated at $39^{\circ} \mathrm{C}$. None of these cultures recommenced growth.

Rumen fluid. In the absence of $10 \%(\mathrm{v} / \mathrm{v})$ autoclaved rumen fluid, or in the presence of particulate fractions A, B or C alone, no growth occurred. AS and FCRF supported a limited amount of growth, and, if AS was combined with $\mathrm{C}$, the growth rate of Q.O. was equivalent to that in autoclaved rumen fluid (ARF) (Fig. I). Fraction $\mathrm{C}$ could not be replaced by boiled Selonomonas ruminantium, cellulose, silica gel, or by petroleum ether $\left(60\right.$ to $80^{\circ} \mathrm{C} \mathrm{b.p}$.), ethylacetate or methanol extracts of fraction C. Combining AS and FCRF with A or B separately did not increase the growth rate over AS alone. If the ARF concentration was decreased to $5 \%$ $(\mathrm{v} / \mathrm{v}) 30 \%$ less growth occurred; if the concentration of ARF was increased to $20 \%(\mathrm{v} / \mathrm{v}) \mathrm{no}$ increase in growth was evident and the cultures were more difficult to examine microscopically due to the presence of a larger quantity of particulate material.

Effect of lactate. In the absence of lactate, growth was erratic and difficult to reproduce, and population densities were low. Growth in different concentrations of sodium lactate, after 6 days of incubation from an inoculum of $18 \times \mathrm{IO}^{4} / \mathrm{ml}$, was (concentration of sodium lactate, g/l; number of organisms $/ \mathrm{ml}): 0,2.6 \times \mathrm{IO}^{4} ; 0.05,30 \times \mathrm{IO}^{4} ; 0 . \mathrm{I}, 82 \times \mathrm{IO}^{4} ; 0.2,76 \times \mathrm{IO}^{4}$.

Volatile fatty acids. The addition of $0 . \mathrm{I} \mathrm{g} / \mathrm{l}$ of sodium acetate, propionate, $n$-butyrate and isobutyrate separately had no effect on growth. $n$-Valerate, isovalerate and DL- $\alpha$-methylbutyrate at $0.088 \mathrm{~g} / \mathrm{l}$ all stimulated growth (Fig. 2) and good growth was obtained when they were combined. $n$-Caproate and isocaproate at $0.088 \mathrm{~g} / 1$ depressed growth by $60 \%$. 


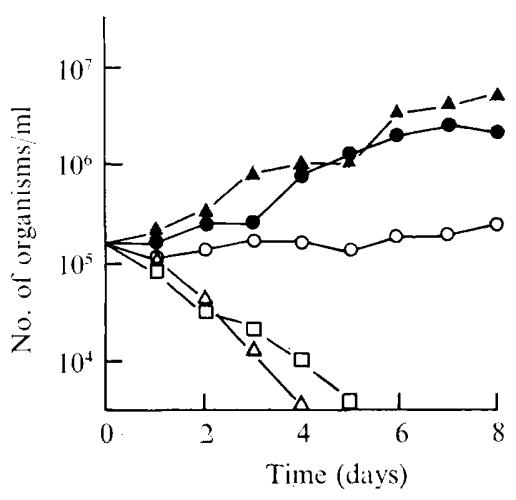

Fig. I

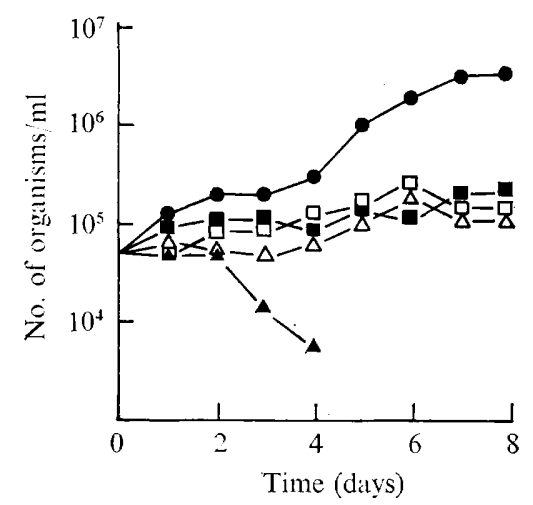

Fig. 2

Fig. 1. Growth of Quin's Oval in the presence of different rumen fluid fractions. Each tube contained rumen fluid - free standard medium $(9.0 \mathrm{ml})$ supplemented with autoclaved rumen fluid or fractions prepared from the equivalent of $\mathrm{I} \cdot 0 \mathrm{ml}$ of autoclaved rumen fluid and $\mathrm{I} \cdot 0 \mathrm{ml}$ of a suspension of Quin's Ovals, incubated at $39^{\circ} \mathrm{C}$. Mannitol $(0.2 \mathrm{~g} / \mathrm{l})$ was added daily to each culture. Cells were counted at daily intervals. The fractions used were: $\boldsymbol{\Lambda}$, autoclaved rumen fluid; $\bigcirc$, autoclaved supernatant ( $12500 \mathrm{~g})$; $\square$, particulate fraction $\mathrm{C}(7500 \mathrm{~g}-\mathrm{I} 2500 \mathrm{~g})$; autoclaved supernatant; $\triangle$, none.

Fig. 2. Growth of Quin's Ovals in the presence of certain volatile fatty acids. Each tube contained standard medium (without volatile fatty acids) supplemented with the volatile fatty acids at $0.088 \mathrm{~g} / \mathrm{l}$. Mannitol $(0.2 \mathrm{~g} / \mathrm{l})$ was added daily to each culture. The cells were counted at daily intervals. The added volatile fatty acids were: $\triangle, n$-valerate; $\square$, isovalerate; $\square$, DL- $\alpha$-methylbutyrate; $\bullet, n$ valerate plus isovalerate plus DL- $\alpha$-methylbutyrate; $\boldsymbol{\Delta}$, none.

Added nitrogen sources. The only nitrogen source in the standard medium was the nitrogenous material present in the ARF. If $0.2 \mathrm{~g} / \mathrm{l}$ of ammonium sulphate, single amino acids, tryptone, yeast extract, casein or albumin were added there was no increase in growth rate of the Q.O. In the presence of tryptone, yeast extract, casein and albumin, bacterial growth became excessive and the Q.O. died.

Alternative carbon and energy sources. The mannitol could be replaced by $0.2 \mathrm{~g} / \mathrm{l}$ of glucose, fructose, mannose or sucrose, but not by arabinose, rhamnose, xylose, lactose, galactose, cellobiose, maltose, trehalose, raffinose, dextrin, cellulose, soluble starch, inulin, or the alcohols sorbitol, ribitol and erythritol. The glycosides salicin and aesculin did not support growth. Suspensions of Q.O. freed of other bacteria stored glycogen in the presence of mannitol, glucose, fructose, mannose and sucrose indicating that they metabolize the carbohydrate directly and do not utilize fermentation products produced from the carbohydrates by other bacteria present in the cultures. Q.O. organisms starved for $40 \mathrm{~h}$ replaced their intracellular glycogen within $\mathrm{I} h$ of being re-incubated in the presence of carbohydrate fermentable by the organism.

Growth in sterile and solid media. None of the organisms selected by micromanipulation grew when incubated in either sterile medium A, medium B, or the medium of Caldwell \& Bryant (I966). No colonies of Q.O. were observed in the same media solidified with agar and inoculated with a suspension of Q.O. grown in vitro and essentially freed of other bacteria, although direct microsopic examination of the agar showed Q.O. to be present and apparently intact. 


\section{DISCUSSION}

The cultural methods used were very similar to those used in the culture in vitro of Eadie's Oval (Orpin, 1972a). Conventional bacteriological techniques could not be employed, since at no time could Q.O. be cultured in a solid medium and therefore no colonies of the organism could be selected for growth in pure culture. As in the case of Eadie's Oval, Q.O. organisms isolated by micromanipulation and incubated singly or in numbers failed to grow in sterile media. This implied that the presence of other bacteria was in some way essential for the growth of Q.O. in vitro under the conditions imposed by the medium used here, unless the organisms were not viable after the micromanipulation process. The contaminating bacteria may influence the growth of Q.O. by their effect on $E_{\mathrm{h}}$, by the supply of a chemical compound required by Q.O. or by the removal of products toxic to Q.O. The death of Q.O. organisms during the micromanipulation process is least likely, for, of the 80 Ovals picked up by micromanipulation and incubated together in non-sterile medium, some organisms were viable.

The requirement for lactate in the culture medium is difficult to explain because lactate is a known product of fermentation of mannitol by Q.O. (Brough et al. 1970). It is possible that an effect was exerted upon the contaminating bacteria and not upon the Q.O. organisms directly. It is also not easy to explain the requirement for a particulate fraction from rumen fluid for growth. The particulate material and the Q.O. fell to the bottom of the culture tube, and the particulate fraction may have acted in the formation of a suitable micro-environment favourable for growth of the Q.O. organisms. It may have acted as a slow-release nitrogen source, stimulating Q.O. growth without allowing an excessive growth of other bacteria.

Since Q.O. can utilize only a limited range of simple carbohydrates, and these are present in the rumen at significant levels only during the time the animal is eating and shortly afterwards, it is essential for Q.O. to be able to store the carbohydrates or some product from them to obtain maximum usage. The glycogen store can enable the organisms to survive for up to $48 \mathrm{~h}$ in the absence of further supplies of fermentable carbohydrate. This ability is shared by Eadie's Oval (Orpin, I972a), which stores glycogen equally rapidly.

I wish to thank Dr P. Kemp for inserting the permanent rumen cannula into the sheep used, Dr J. M. Eadie for assistance in identifying the organisms, and Miss H. P. I. Patmore for valuable technical assistance.

\section{REFERENCES}

Abou Akkada, A. R., Bartley, E. E., Berube, R., Fina, L. R., Meyer, R. M., Hendricks, D. \& Julius, F. (I968). Simple method to remove completely ciliate protozoa from adult ruminants. Applied Microbiology 16, I 475-I 477 .

Brough, B. E. \& Howard, B. H. (1970). The biochemistry of the rumen bacterium 'Quin's Oval' - Part 2. The carbohydrase enzymes. New Zealand Journal of Science I3, 576-583.

Brough, B. E., Reid, T. C. \& Howard, B. H. (1970). The biochemistry of the rumen bacterium 'Quin's Oval' - Part 2. Fermentation of carbohydrates. New Zealand Journal of Science 13, 570-575.

Caldwell, D. R. \& BRyant, M. P. (1966). Medium without rumen fluid for non-selective enumeration and isolation of rumen bacteria. Applied Microbiology 14, 794-80I.

Every, D. D. \& Howard, B. H. (I970). The biochemistry of the rumen bacterium 'Quin's Oval' - Part 3. The storage polysaccharide. New Zealand Journal of Science 13, 584-590.

Hungate, R. E. (1966). The Rumen and its Microbes, p. 13. New York: Academic Press.

IngRam, M. \& MCGaughey, C. A. (1948). Microflora of the rumen of sheep. Nature, London I62, 533. 
MCCarthy, D. H. \& Stevenson, J. P. ( 1 972). Bacterial flagella staining. Laboratory Practice 21, $267-268$.

OrPIN, C. G. (1971). The re-establishment of Eadie's Ovals, grown in vitro, in the rumen of a defaunated sheep. Journal of General Microbiology 68, xvii.

OrPIN, C. G. (I972a). The culture of the rumen organism Eadie's Oval in vitro. Journal of General Microbiology 70, $32 \mathrm{I}-329$.

Orpin, C. G. (1972 b). The in vitro culture of Quin's Oval. Journal of Applied Bacteriology (in the Press).

Oxford, A. E. (1955). Some observations upon the status of the generic name Selenomonas Prowazek. International Bulletin of Bacterial Nomenclature and Taxonomy 6, I3I-I32.

PARK, J. T. \& Johnson, M. J. (1949). A submicrodetermination of glucose. Journal of Biological Chemistry I8I, I 49-I 5I.

Purdom, M. R. (1963). Micromanipulation in the examination of rumen bacteria. Nature, London r98, 307-308.

Quin, J. I. (1943). Studies on the alimentary tract of Merino sheep in South Africa. VII. Fermentation in the forestomachs of sheep. Onderstpoort Journal of Veterinary Science and Animal Industry 18, 9I-II 2.

van Der Westhuizen, G. C. A., Oxford, A. E. \& Quin, J. I. (1950). Studies on the alimentary tract of Merino sheep in South Africa. XVI. On the identity of Schizosaccharomyces ovis. Part I. Some yeast-like organisms isolated from the rumen contents of sheep fed on a lucerne diet. Onderstpoort Journal of Veterinary Science and Animal Indsutry 24, I I9-124.

WiCken, A. J. \& HowARD, B. H. (I967). On the taxonomic status of Quin's Oval organisms. Journal of General Microbiology 47, 207--2 I I.

Woodcock, H. M. \& LAPAGE, G. (19I3). On a remarkable type of protistan parasite. Quarterly Journal of Microscopical Science 59, 43 I-458. 